\title{
PENGEMBANGAN MODUL MATERI BARISAN DAN DERET KELAS X SMK DENGAN PENDEKATAN REACT
}

\author{
Kristina Kewa Sili1, Siti Napfiah'2, Anik Kurniawati ${ }^{3}$ \\ 1,2,3 IKIP Budi Utomo Malang \\ napfiahsiti@gmail.com
}

\begin{abstract}
Abstrak
Modul sebagai salah satu bahan ajar yang dapat digunakan untuk meningkatkan kualitas pembelajaran. Sebagian besar siswa terkendala belajar matematika karena menurut mereka matematika itu abstrak. Berdasakan hal ini dikembangkanlah modul yang mengaitkan materi dengan kehidupan nyata siswa. Salah satu pendekatan dalam matematika yang berkaitan dengan kehidupan nyata siswa adalah pendekatan REACT (Relating, Experiencing, Applying, Cooperating, Transferring). Tujuan penelitian ini adalah mengembangkan modul yang valid dan paktis pada materi Barisan dan Deret dengan pendekatan REACT. Jenis penelitian ini yaitu penelitian pengembangan ADDIE yang meliputi lima tahapan pokok, yaitu analysis (analisis), design (perancangan), development (pengembangan), implementation (implementasi), dan evaluation (evaluasi). Instrumen yang digunakan yakni lembar validasi ahli materi, lembar validasi ahli media, dan angket respons siswa. Subjek penelitian ini adalah siswa SMK Negeri Ile Boleng kelas X. Kevalidan modul mencapai persentase skor ratarata $77 \%$. Dilihat dari aspek kepraktisan, modul dinyatakan praktis dengan persentase skor rata-rata 95\% dengan kategori sangat baik.
\end{abstract}

Kata kunci: modul, REACT, barisan, deret

\begin{abstract}
Module constitutes one of material teach applicable to increase learning quality. Largely student most constraint studies mathematics because terminological they that mathematics abstraction. Berdasakan it is developed module which concern material with student real life. One of approaching in mathematics that gets bearing with student real life is REACT'S approaching (Relating, Experiencing, Applying, Cooperating, Transferring). To the effect this research is develop module that valid and paktis on Line and Line material with REACT'S approaching. This observational type constitute development research with model developmental ADDIE who covers five subject steps, which is analysis, design, development, implementation, and evaluation. Instrument that is utilized is sheet validate material pro, sheet validates media pro, and student response questionnaire. Subjek is this research is SMK'S student Ile Boleng's Country brazes X. Kevalidan
\end{abstract}


module reaches score percentage average $77 \%$. Seen from practicability aspect, practical stated module with score percentage average $95 \%$ by pretty good categories.

Keywords: module, REACT, sequence, series

\section{PENDAHULUAN}

Pada era modern ini, persaingan antar negara semakin ketat. Persaingan tersebut mendorong negara-negara di dunia, termasuk Indonesia untuk mempersiapkan dirinya di berbagai sektor. Salah satunya adalah sektor pendidikan. Pada sektor pendidikan, manusiamanusia dipersiapkan untuk memiliki sumber daya yang berkualitas agar dapat bersaing di era modern. Berdasarkan UndangUndang Sistem Pendidikan Indonesia Nomor 20 tahun 2003 pasal 1, Pendidikan Indonesia dibagi ke dalam pendidikan formal, nonformal dan informal. Pendidikan formal dibagi ke dalam tiga jenjang, dimulai dari pendidikan dasar, pendidikan menengah dan pendidikan tinggi.

Matematika tidak terlepas dari kehidupan manusia karena Matematika mempunyai peranan yang sangat penting di dalam dunia pendidikan. Pendidikan sebagai pengalaman belajar di berbagai lingkungan yang berlangsung sepanjang hayat dan berpengaruh positif bagi perkembangan individu karena dalam pendidikan mengandung pengetahuan serta nilai-nilai dan keterampilan yang diperlukan. Oleh karena itu Matematika diajarkan di lembaga pendidikan formal.

Berdasarkan hal tesebut, matematika harus dipelajari oleh siswa pada setiap jenjang pendidikan dimulai dari taman kanak-kanak sampai perguruan tinggi. Bahkan di sekolah, matematika memiliki porsi waktu belajar yang lebih banyak dibandingkan dengan mata pelajaran yang lain. Namun yang menjadi permasalahan, secara umum banyak sekali anak Indonesia yang tidak suka pelajaran matematika. Menurut pendapat Saleh (dalam Trilutfia, 2015: 1), siswa merasa mata pelajaran matematika itu sulit dan menakutkan. Karena itulah sebagian besar siswa tidak memahami makna pembelajaran yang diperoleh sehingga tidak mampu menghubungkan antara materi yang dipelajari terhadap kegunaannya dalam kehidupan, sehingga sbagian besar dari mereka hanya mampu sampai tingkat hafalan terhadap materi yang diterima.

Berdasarkan masalah tersebut, maka upaya untuk mengatasinya yaitu pembelajaran sebaiknya diberikan dengan memperhatikan konteks siswa dan mengaitkan materi dengan kehidupan nyata. 
Konteks nyata dari kehidupan siswa meliputi latar belakang fisik, keluarga, keadaan sosial, politik, agama, budaya dan kenyataan hidup lainnya, menurut Moch. Masykur dan Fathoni (dalam Kurniati, 2016: 2). Pembelajaran yang dilakukan dengan memperhatikan konteks siswa dan mengaitkan materi dengan kehidupan nyata akan dapat membantu pemerintah dalam rangka meningkatkan mutu pendidikan nasional yang berfungsi mengembangkan kemampuan dan membentuk watak serta peradaban bangsa yang bermartabat, dalam rangka mencerdaskan kehidupan bangsa, yang bertujuan untuk mengembangkan potensi siswa agar menjadi manusia yang beriman dan bertaqwa kepada Tuhan yang Maha Esa, berakhlak mulia, sehat, berilmu, cakap, kreatif, mandiri, dan menjadi warga negara yang demokratis serta bertanggung jawab (UndangUndang Sistem Pendidikan Nasional No 20 Tahun 2003, Bab II, Pasal 3).

Proses pembelajaran terdiri dari beberapa komponen yang saling berinteraksi. Menurut Winarno (dalam Faidah, 2016: 5), ada tujuh komponen belajar mengajar yaitu tujuan belajar, bahan belajar, siswa, guru, metode pembelajaran, situasi, dan evaluasi. Guru berperan penting sebagai pemandu dan fasilitator dalam proses berlangsungnya pembelajaran. Guru harus menciptakan kondisi belajar yang menyenangkan agar siswa termotivasi untuk belajar. Menurut Damadi (dalam Faidah, 2016: 5), materi pembelajaran (bahan ajar) merupakan salah satu komponen sistem pembelajaran yang memegang peranan penting dalam membantu siswa mencapai standar kompetensi dan kompetensi dasar. Dengan begitu, guru harus merencanakan rancangan proses belajar dan materi belajar sebelum menerapkan pembelajaran di kelas. Guru juga harus menentukan strategi dan metode yang efektif untuk digunakan di kelas karena guru yang lebih mengetahui karakteristik siswa.

Peraturan Menteri Pendidikan Nasional (permendiknas) nomor 41 tahun 2007 tentang standar proses, salah satunya mengatur tentang perencanaan proses pembelajaran yang secara implisit menyatakan bahwa guru diharapkan mampu mengembangkan bahan ajar sebagai salah satu sumber belajar. Bahan ajar yang dikembangkan tersebut diharapkan lebih sesuai, karena guru berhubungan langsung dengan siswa. Bahan ajar memungkinkan siswa dapat mempelajari suatu kompetensi secara mandiri, runtut dan sistematis sehingga mampu menguasai semua kompetensi 
secara utuh dan terpadu. Dengan demikian, perlu dikembangkan bahan ajar yang sesuai dengan kebutuhan demi tercapainya tujuan pembelajaran yang diinginkan.

Bahan ajar sebagai salah satu sumber belajar siswa. Agar bahan ajar yang digunakan dapat memfasilitasi siswa untuk mencapai tujuan pembelajaran, maka seorang guru harus mendesain bahan ajar sendiri sesuai dengan kebutuhan dan karakteristik siswa. Pembelajaran matematika seharusnya dikaitkan dengan kehidupan nyata karena matematika adalah aktivitas manusia, matematika lahir dan tumbuh dari aktivitas manusia (Ibrahim dan Suparni (dalam Faidah, 2016: 8)).

Menurut Komalasari (2010: 89), bahwa pembelajaran kontekstual difokuskan pada REACT (Relating, Experiencing,

Applying, Cooperating, dan Transferring). Pembelajaran yang berlangsung selama ini, pada umumnya pengetahuan yang dimiliki siswa tidak dikaitkan (relating) dengan pengetahuan yang berhubungan dengan materi yang akan dipelajari. Siswa seolah-olah tidak membutuhkan relasi atau mengaitkan pengetahuannya dengan pengetahuan baru. Padahal ini sangat penting bagi pengetahuan jangka panjang siswa. Eksperimen (experiencing) siswa dalam menggali pengetahuan baru juga masih sangat minim. Akan lebih baik jika dalam menanamkan sebuah konsep baru, siswa dibimbing dengan permasalahanpermasalahan yang berhubungan dengan kehidupan sehari-hari siswa. Pengaplikasian (applying) pengetahuan siswa ke dalam permasalahan yang berhubungan dengan kehidupan sehari-hari sangat membantu siswa memperkuat pemahaman konsep dan kebermaknaan belajar siswa. Pembelajaran akan lebih memotivasi siswa jika dilaksanakan dengan berdiskusi (cooperating) dengan teman sebayanya. Pengetahuan dan pemahaman yang telah dimiliki siswa, selanjutnya guru memfasilitasi siswa untuk mentransfer (transfering) pengetahuannya ke dalam sebuah bahasa matematika atau simbol pada matematika. Artinya pengetahuan yang bersifat konkrit yang telah dikuasai oleh siswa dibawa ke dalam pemahaman yang sifatnya abstrak. Hal ini bertujuan agar sifat abstrak matematika dapat dengan mudah diterima oleh siswa. Sehingga keabstrakan matematika tidak hampa arti bagi siswa. Oleh karena itu, guru harus mendesain bahan ajar yang dapat mengaitkan materi dengan masalah-masalah yang ada dalam kehidupan nyata siswa. Bahan ajar yang dapat mengaitkan materi dengan kehidupan nyata siswa 
adalah bahan ajar dalam bentuk modul berbasis pendekatan REACT ((Relating, Experiencing, Applying, Cooperating, dan Transferring).

Modul merupakan salah satu bentuk bahan ajar yang dikemas secara utuh dan sistematis, di dalamnya memuat seperangkat pengalaman belajar yang terencana dan didesain untuk membentuk siswa menguasai tujuan belajar yang spesifik. Modul minimal memuat tujuan pembelajaran, materi atau substansi belajar, dan evaluasi. Modul berfungsi sebagai sarana belajar yang bersifat mandiri, sehingga siswa dapat belajar secara mandiri sesuai dengan kecepatan masing-masing (Darmiatun, 2013: 9). Modulmemiliki sifat membantu dan mendorong pembacanya untuk mampu membelajarkan diri sendiri (self instructional) dan tidak bergantung pada media lain (self alone) dalam penggunaannya. Modul juga memiliki sifat self contained, artinya dikemas dalam satu kesatuan yang utuh untuk mencapai kompentensi tersebut (Hamdani, 2011: 219).

Barisan dan deret merupakan salah satu materi yang dipelajari siswa kelas X semester genap pada KTSP. Pada materi ini siswa dituntut untuk menguasai konsep barisan dan deret. Tetapi kebanyakan siswa tidak dapat menghubungkan pengetahuan sebelumnya untuk menyelesaikan masalah yang diberikan. Dalam materi ini, biasanya siswa hanya menghafal rumus-rumus jadi untuk menyelesaikan soal-soal prosedural. Hal ini karena soalsoal yang diberikan guru tidak variatif. Guru hanya mengambil soal-soal yang ada di buku-buku tanpa dimodifikasi sehingga siswa tidak dapat berpikir kritis, logis, analisis, dan bernalar. Dari permasalahan tersebut, peneliti berpikir bahwa perlu adanya pengembangan modul pada materi barisan dan deret. Khususnya pada standar kompetensi yang diharapkan dapat dicapai siswa pada penelitian ini yaitu menerapkan konsep barisan dan deret dalam pemecahan masalah.

\section{METODE PENELITIAN}

Jenis penelitian ini adalah penelitian pengembangan, yaitu suatu penelitian yang bertujuan untuk mengembangkan suatu produk. Produk yang dihasilkan dalam penelitian ini adalah modul dengan pendekatan REACT pada materi barisan dan deret. Modul yang dihasilkan ini, akan divalidasi terlebih dahulu untuk melihat kevalidannya. Setelah modul dikatakan valid, modul tersebut diujicobakan kepada siswa untuk melihat keefektivannya.

Model pengembangan yang digunakan pada modul ini adalah model pengembangan ADDIE. Model pengembangan ADDIE 
terdiri atas lima tahap pengembangan yaitu analysis (analisis), design(desain), development

(pengembangan),implementation (implementasi), dan evaluation (evaluasi).

1) Tahap Analisis (Analysis)

Tahap analisis merupakan suatu proses yang akan mendefinisikan apa yang akan dipelajari oleh siswa, maka untuk mengetahui atau menentukan apa yang harus dipelajari, kita harus melakukan beberapa kegiatan, diantaranya adalah:

a) Melakukan analisis karakteristik siswa yaitu untuk menentukan kemampuan-kemampuan atau kompetensi yang perlu dipelajari oleh siswa untuk meningkatkan hasil belajar.

b) Analisis kurikulum dilakukan dengan melakukan studi pustaka yang meliputi analisis Standar Kompetensi (SK), Kompetensi Dasar (KD), materi, dan indikator pembelajaran yang mengacu pada Kurikulum Tingkat Satuan Pendidikan (KTSP).

2) Tahap Perancangan (Design) Tahap ini dikenal juga dengan istilah membuat rancangan. Tujuan tahap perancangan adalah untuk mempersiapkan segalahal yang dibutuhkan dalam pengembangan modul agar modul yang dikembangkan dapat mendukung pembelajaran di sekolah. Kegiatan perancangan meliputi empat hal:

a) Menyiapkan buku referensi yang berkaitan dengan materi barisan dan deret.

b) Menyusun kerangka modul sesuai dengan sistematika penyusunan materi yang akan digunakan dalam mengembangkan suatu produk.

c) Menentukan desain tampilan modul agar modul tersusun secara rapidan terencana.

d) Penyusunan desain instrumen penilaian dengan tujuan agar alat untuk menilai modul yang dikembangkan benar-benar valid sebelum digunakan. Instrumen penilaian yang dikembangkan, divalidasi kepada ahlinya.

3) Tahap Pengembangan (Development)

Tujuan tahappengembangan adalah untuk mengembangkan modul guna mencapai tujuan pembelajaranyang telah dirumuskan sebelumnya. Secara rinci, langkah-langkah yang dilakukan pada tahap ini adalah sebagai berikut:

a) Mengembangkan modul dengan pendekatan REACT(relating, 
experiencing, applying, cooperating, dan transferring)sesuai dengan hasil perancangan.

b) Mengembangkan instrumen penilaian akan didasarkan pada poin-poin syarat modul yang baik.

c) Menilai kualitas modul (validasi modul) sebelum diujicobakan dalam pembelajaran di sekolah. Kevalidan modul yang dikembangkan akan dilakukan oleh ahli materi dan ahli media.

d) Melakukan revisi produk dan instrumensetelah modul divalidasi. Revisi produk disesuaikan dengan saran dari ahli materi dan ahli media.

4) Tahap Implementasi (Implementation)

Tahap implementasi adalah langkah nyata untuk mengujicobakan produk. Dalam langkah ini modul diujicobakan secara terbatas dengan mengambil 10 siswa pada kelas $\mathrm{X}$ yang sudah menerima pelajaran barisan dan deret untuk mengisi angket respons siswa terhadap modul matematika yang dihasilkan. Siswa dipilih secara acak oleh guru mata pelajaran

matematika,berdasarkan

tingkat kemampuan siswa dalam memahami pelajaran matematika atau dari tingkat prestasi belajar siswa, mulai dari tingkat prestasi rendah, sedang, dan tinggi.

5) Tahap Evaluasi (Evaluation) Tahap evaluasi adalah proses untuk melihat apakah modul yang dikembangkan berhasil sesuai dengan harapan awal atau tidak. Pada tahap evaluasi, peneliti mengevaluasi hal yang terkait dengan pengembangan modul antara lain: a) Melakukan revisi akhir setelah modul yang dikembangkan diimplementasikan dalam pembelajaran matematika, b) Menghasilkan produk akhir yang layak digunakan dalam pembelajaran matematika di sekolah.

\section{HASIL DAN PEMBAHASAN}

Penelitian ini bertujuan mengembangkan modul dengan pendekatan REACT (Relating, Experiencing, Applying, Cooperating, Transferring) pada materi Barisan dan Deret untuk SMK kelas X. Pengembangan modul yang digunakan adalah model pengembangan ADDIE, yang meliputi tahap Analysis (analisis), Design (perancangan), Development (pengembangan), Implementation (implementasi), dan Evaluation (evaluasi). Berikut ini hasil penelitian dan pembahasan setiap tahapan pengembangan modul tersebut. 


\section{Tahap Analisis (Analysis)}

Hal-hal yang dianalisis meliputi kurikulum dan kebutuhan siswa kelas X SMK Negeri Ile Boleng yang berkaitan dengan materi barisan dan deret. Proses yang dilakukan pada tahap analisis adalah sebagai berikut.

1. Analisis Kurikulum

Kurikulum yang digunakan di SMK Negeri Ile Boleng adalah Kurikulum Tingkat Satuan Pendidikan (KTSP). Sehingga penyusunan dan pengembangan modul juga menggunakan Kurikulum Tingkat Satuan Pendidikan (KTSP) sesuai kurikulum yang digunakan di sekolah tersebut.Pada tahap analisis, peneliti mengidentifikasi Standar Kompetensi (SK) dan Kompetensi Dasar (KD) yang dibutuhkan dalam pengembangan modul matematika pada materi barisan dan deret dengan menggunakan pendekatan REACT (Relating, Experiencing, Applying, Cooperating, Transferring). Karena penyusunan dan pengembangan modul menggunakan Kurikulum Tingkat Satuan Pendidikan (KTSP), maka modul yang dikembangkan harus sesuai dengan SK (Standar Kompetensi) dan KD (Kompetensi Dasar).

2. Analisis Karakteristik Siswa
Karakteristik siswa di SMK Negeri Ile Boleng terkhususnya kelas $\mathrm{X}$ berbeda-beda dan kemampuan menyerap pelajaran juga berbeda terutama dalam mata pelajaran matematika. Banyak siswa yang belum mampu memahami materi yang telah dijelaskan oleh guru, sulit menghafal rumus, kurang tertarik dengan mata pelajaran matematika, dan menganggap matematika itu sulit. Karena hal tersebut, maka peneliti mencoba mengembangkan modul dengan pendekatan REACT (Relating, Experiencing, Applying, Cooperating, Transferring) agar siswa lebih mudah memahami materi, karena dalam pendekatan REACT (Relating, Experiencing, Applying, Cooperating, Transferring), permasalahan dan penyampaian materi dikaitkan dengan kehidupan nyata siswa.

\section{Tahap Perancangan (Design)}

Hasil tahap analisis digunakan sebagai dasar dalam membuat modul. Hal-hal yang dilakukan pada tahap desain yaitumenyiapkan materi yang berkaitan dengan materi barisan dan deret, menyusun peta konsep modul, penyusunan desain modul dan penyusunan desain instrumen. Proses pertama yang dilakukan pada tahap desain diuraikan sebagai berikut: (1) Menyiapkan 
buku referensi yang berkaitan dengan materi barisan dan deret. Referensi yang digunakan dalam penulisan modul yaitu dengan menggunakan buku-buku pelajaran atau buku bacaan yang di dalamnya terdapat pembahasan tentang materi barisan dan deret, serta buku kumpulan soal-soal yang digunakan untuk menyusun soal evaluasi. (2) Untuk memudahkan proses penyusunan modul, maka dibuat kerangka modul.

\section{Tahap \\ Pengembangan (Development)}

Sebagai tindak lanjut atas rancangan yang telah dilakukan dalam tahap design, maka kegiatan yang dilakukan pada tahap ini adalah sebagai berikut.

\section{Pra Penulisan}

Pengkajian bahan materi dalam modul dilakukan dengan pengumpulan sumber dan referensi serta gambargambar yang berhubungan dengan materi Barisan dan Deret.

\section{Penulisan Draft Modul}

Pada penulisan draft modul ini, garis besar isi modul dikembangkan menjadi suatu bahan ajar dengan pendekatan REACT (Relating, Experiencing, Applying, Cooperating, Transferring). Draft modul yang disajikan dengan pendekatan REACT (Relating, Experiencing, Applying, Cooperating,
Transferring)dikembangkan

menjadi modul dengan rancangan awal, sebagai berikut.

a. Sampul modul

Halaman sampul modul terdiri dari judul, gambar, pendekatan yang digunakan, identitas penulis, tujuan pengembangan, dan sasaran pengguna modul. Gambar yang dipilih disesuaikan dengan materi pembelajaran barisan dan deret yang dikemas dengan gambar dan warna yang menarik. Tampilan gambar yang digunakan pada halaman sampul berkaitan dengan kehidupan nyata dan bersesuaian dengan materi yang dibahas di dalam modul, sehingga konsep sampul sesuai dengan pendekatan yang digunakan yaitu pendekatan REACT (Relating, Experiencing, Applying, Cooperating, Transferring). Tujuan pengembangan modul dan identitas penulis tercantum pada halaman belakang sampul. Sampul dikemas sedemikian rupa agar siswa maupun pembaca memiliki gambaran tentang modul sebelum membaca isinya.

b. Halaman Francis 


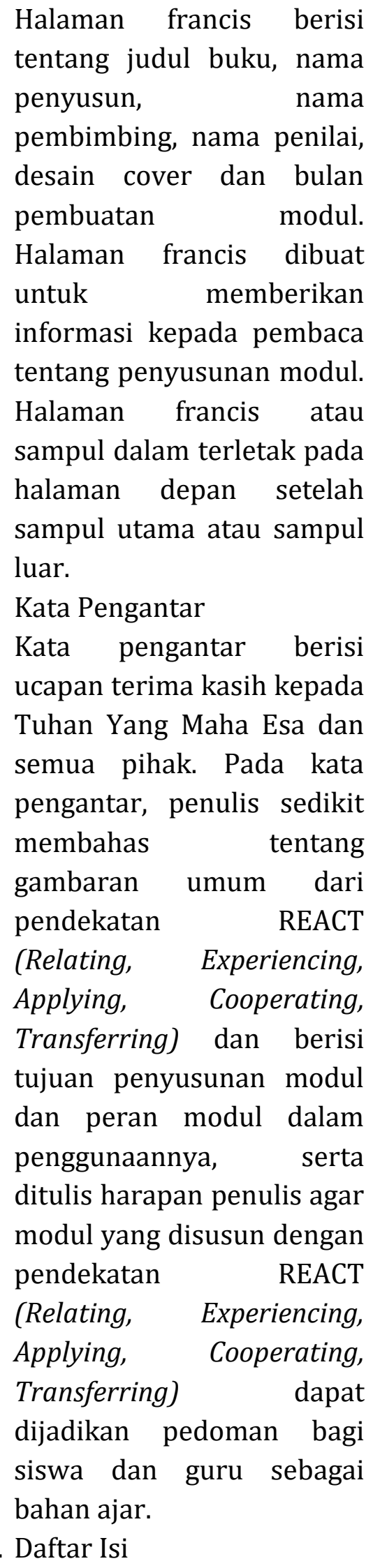

\begin{abstract}
Daftar isi berisi materi yang diikuti dengan halaman kemunculan pada modul. Daftar isi berfungsi memudahkan siswa dalam menentukan halaman setiap sub bab pokok bahasan yang akan dipelajari.

e. Kegiatan Belajar

Dalam modul ini, penyampaian materi disusun secara jelas. Pemisahan materi dilakukan dalam beberapa kegiatan belajar. Hal tersebut bertujuan agar materi dapat dipelajari dengan mudah. Setiap kegiatan belajar memiliki beberapa komponen antara lain uraian materi, kegiatan siswa, contoh soal, latihan soal, rangkuman, evaluasi, soal uraian, kunci jawaban, dan glosarium.
\end{abstract}

\section{Penyuntingan}

Setelah melalui tahap penulisan, maka diperoleh draft modul awal. Selanjutnya draft modul awal tesebut dikonsultasikan kepada dosen pembimbing untuk mendapatkan saran perbaikan. Draft modul yang telah dikonsultasikan tersebut direvisi sesuai saran dan petunjuk dosen pembimbing. Setelah selesai direvisi, selanjutnya draft modul 
divalidasi oleh ahli materi dan ahli media.

4. Validasi dan Penilaian Modul

Validasi modul bertujuan untuk mengetahui kekurangan dan kelebihan modul, selanjutnya setelah modul divalidasi akan dilakukan revisi sesuai saran validator. Validasi penilaian untuk ahli materi dan ahli media dilakukan oleh dosen Prodi Pendidikan Matematika IKIP Budi Utomo Malang. Berikut ini hasil dari validasi yang telah dilakukan oleh kedua validator terhadap modul barisan dan deret.

Berdasarkan analisis data yang disajikan pada tabel di atas, maka diperoleh hasil penilaian oleh validator I dengan skor rata-rata 3,08 dengan kategori baik dan hasil penilaian validator II dengan skor rata-rata 3,08 dengan kategori baik. Hasil penilaian dari validator I dan II dapat dilihat pada lampiran.

Dengan demikian, diperoleh total skor rata-rata oleh validator I dan validator II yaitu 3,08 dengan kategori baik. Maka dapat disimpulkan, bahwa modul yang dikembangkan dinyatakan valid.

\section{Revisi Produk}

Revisi produk dilakukan setelah modul divalidasikan kepada para ahli.

Tahap Implementasi

\section{(Implementation)}

Setelah modul divalidasi oleh ahli media dan ahli materi, kemudian modul direvisi sesuai saran validator. Setelah itu, peneliti melakukan implementasi terhadap modul yang telah dihasilkan dengan menyebarkan angket respons siswa terhadap modul barisan dan deret pada tanggal 11 April 2018 di SMK Negeri Ile Boleng. Angket respons siswa terhadap modul barisan dan deret terdapat 15 pernyataan dengan alternatif pilihan sangat setuju, setuju, kurang setuju dan tidak setuju.

\section{Tahap Evaluasi (Evaluation)}

Modul yang telah dikembangkan dievaluasi dengan menganalisis angket respons siswa terhadap modul barisan dan deret. Dalam evaluasi ini, peneliti melibatkan 10 siswa. Selanjutnya peneliti menganalisis data dari pengisian angket respons siswa yang telah diperoleh.

Hasil evaluasi yang diperoleh dari pengisian angket respons siswa adalah dengan skor rata-rata 3,8 yang dapat dikategorikan sangat baik. Dengan demikian, berdasarkan skor rata-rata yang diperoleh dari hasil pengisian angket respons siswa, maka modul dapat dinyatakan efektif untuk digunakan sebagai sumber belajar. 


\section{KESIMPULAN DAN SARAN}

Berdasarkan pembahasan pada bab IV, dapat disimpulkan sebagai berikut. (1) Pengembangan modul dengan pendekatan REACT (Relating, Experiencing, Applying, Cooperating, Transferring) pada materi barisan dan deret untuk siswa kelas X SMK dilakukan dengan model pengembangan ADDIE yang terdiri dari tahap analysis (analisis), design (desain), development (pengembangan), implementation (implementasi) dan evalution (evaluasi). (2) Kualitas modul pada materi barisan dan deret untuk siswa SMK kelas $\mathrm{X}$ yang telah dikembangkan adalah:

a. Modul yang dikembangkan dengan pendekatan REACT (Relating, Experiencing, Applying, Cooperating, Transferring) dinyatakan valid dengan skor rata-rata validator I adalah 3,08danvalidator II dengan skor rata-rata 3,08 , sehingga total skor rata-rata yang diperoleh dari validator I dan validator II adalah 3,08 dengan kategori valid.

b. Modul yang dikembangkan dengan pendekatan REACT (Relating, Experiencing, Applying, Cooperating, Transferring) dinyatakan efektif dengan skor rata-rata 3,8 dan menunjukan kategori sangat baik.

Saran yang dapat diberikan berdasarkan penelitian yang telah dilakukan adalah sebagai berikut. (1) Modul dengan pendekatan REACT (Relating, Experiencing, Applying, Cooperating, Transferring) ini telah diuji kevalidan dan keefektifannya, sehingga disarankan para guru dan siswa untuk menggunakannya sebagai salah satu alternatif sumber belajar pada materi barisan dan deret untuk siswa kelas X SMK. (2) Penulis menghimbau kepada peneliti lainnya agar dapat menggunakan angket respons siswa dalam jumlah yang lebih banyak lagi, sehingga dapat diketahui hasil penelitian yang lebih baik lagi.

\section{DAFTAR PUSTAKA}

Darmiatun, Suryatri. 2013. Menyusun modul Bahan Ajar untuk Persiapan Guru dalam Mengajar. Malang: Gava Media.

Faidah, Nur. 2016. Pengembangan Bahan Ajar Matematika Berbasis Kontekstual REACT (Relating, Experiencing, Applying, Cooperating, and Transferring) untuk Memfasilitasi Kemampuan Pemahaman Konsep dan Pemecahan Masalah Siswa Kelas XI pada Materi Fungsi Komposisi dan Fungsi Invers. Skripsi. Yogyakarta: Universitas Islam Negeri Sunan Kalijaga Yogyakarta.

Hamdani. 2010. Strategi Belajar Mengajar. Bandung: Pustaka Setia. 
Sili, K.K., Napfiah S., Kurniawati, A.

Pengembangan Modul Materi Barisan dan Deret Kelas X SMK dengan Pendekatan REACT

Komalasari, $\quad$ Kokom. 2010.

Pembelajaran Kontekstual Konsep dan Aplikasi. Bandung: Refika Aditama.

Kurniati, Annisah. 2016. Pengembangan Modul Matematika Berbasis Kontekstual Terintegrasi Ilmu Keislaman. Jurnal Al Khawarizmi, 4(1); 43-58.

Trilutfia. 2015. Pengaruh Pendekatan Kontekstual Strategi REACT Terhadap Hasil Belajar Matematika Siswa. Skripsi. Jakarta: Universitas Islam Negeri (UIN) Syarif Hidayatullah Jakarta. 